\title{
The Influence of Reputation Events on the Market Value of China's Listed Commercial Banks*
}

\author{
Ruibo Liu \\ School of Finance \\ Shandong University of Finance and Economics \\ Yanshan College Shandong University of Finance and \\ Economics \\ Jinan, China
}

\author{
Min Liu** \\ School of Finance \\ Shandong University of Finance and Economics \\ Jinan, China \\ **Corresponding Author
}

\begin{abstract}
In the "Report on the Work of the State Council of the State Council in 2018", the three tough battles are proposed for the first time, which will promote significant progress in the prevention and resolution of major risks as the focus of the national economic work in 2018. Reputation risk, as one of the eight risks faced by commercial banks, has a greater impact on listed commercial banks. This paper adopts the event study method, using 68 negative reputation events of China's 14 listed commercial banks from 2010 to 2018 as samples to study the impact of reputation events on the market value of listed commercial banks. Research shows that negative reputation events will lead to significantly negative excess returns on the announcement date, which shows that reputation events have an important impact on the market value of listed commercial banks. Under the modern economic situation, listed commercial banks should pay more attention to the management of reputation risk.
\end{abstract} value

Keywords—reputation events; listed commercial bank; market

\section{INTRODUCTION}

Ever since Adam Smith began, economists have realized that reputation plays an important role in transactions, but the widespread concern for reputation risk is after the 2008 financial crisis. The financial crisis in 2008 led to the bankruptcy of many old banks. Reputation has played an important role. In January 2009, the Basel Committee clearly listed reputation risk as the second pillar in the new capital agreement and defined the importance of reputation risk management from an international perspective. China also promulgated the "Guidelines for Commercial Banks Reputation Risk Management" on August 25 2009, clarifying that commercial banks should incorporate reputation risk into the risk management system and establish a contingency plan for reputation events. In the 2017, Central Economic Work Conference pointed out that in accordance with the requirements of the 19th National Party Congress, preventing and resolving major risks should be focused on in the next three years. The report of the Nineteenth Party Congress proposed that the financial supervision system should be established to protect the bottom line of systemic financial risks.

*This research was financially supported by the National Science Foundation 16BGL045.
Preventing the occurrence of systemic financial risks is a fundamental task of financial work, and it is necessary to take the initiative to prevent and resolve systemic financial risks in a more important position. The commercial bank is a special institution which manages money and capital, and has an important position in the entire financial system and even the national economy. As one of the eight major risks of commercial banks, the prevention work of reputation risk plays a decisive role in its business development and long-term operation. This article quantifies the impact of reputation events through the event research method and uses 68 reputation events of 14 commercial banks from 2010 to 2018 as samples to study the impact of reputation events on the market value of listed commercial banks.

\section{THE RESEARCH STATUS AT HOME AND ABROAD OF COMMERCIAL BANK REPUTATION}

For the research on the reputation of commercial banks, foreign studies mainly focus on the relationship between the reputation of commercial banks and the bank run, the impact on the bond market and so on. Many foreign scholars have studied the relationship between commercial bank reputation and bank run. Gary Gorton [1] introduces noise index to study the reputation risk of commercial banks, and points out that joining bank operating performance or contract design can effectively inhibit bank reputation crisis. DW Diamond [2] studies the formation process of bank reputation in the bond market. The author finds that when a bank issues a bond for the first time, compared to a bank with the same level but a credit history, its issuance interest rate is usually high. After a period of time, its interest rate gradually decreased until it was equal to a bank with the same credit history. In this process, the value of the bank's reputation gradually increases with time. If a good reputation is obtained, reputation will provide a better incentive $\mathbf{J}$ Corbett and $\mathbf{J}$ Mitchell [3] study the relationship between private bank reputation and government assistance, and point out that reputation affect the efficiency of government relief. In many cases, when the banks go through a crisis, government agencies provide bank rescue plans. However, one of the reasons that banks do not accept is concerns about the reputation of banks and they are reluctant to accept restructuring. 
Domestic scholars have been working hard to quantify the reputation risk of commercial banks. Chinese scholars Zhang and $\mathrm{Hu}$ [4] learn from RQ reputation quotient measurement method and use Bayesian network model to empirically demonstrate that corporate charisma, service and product, and lack of risk control are the main factors affecting the reputation risk of commercial banks in China. Bi [5] sets up early warning indicators of bank reputation risk based on Harris-Fombrun model and finds that the factors affecting state-owned holding banks and joint-stock banks are different. Li [6] learns from the Rep Trak model and uses analytic hierarchy process and factor analysis to empirically discover that asset liquidity, products and services, and innovation and risk control have the greatest impact on the reputation of commercial banks. Hu and Han [7] base on the reputation risk loss data of a bank within ten years, and calculate the total reputation risk economic capital demand of the commercial bank using the Monte Carlo simulation method; Pi and Yang [8] determine the reputation effects of commercial banks by separating the losses caused by operational risks and the loss of market value, and study the effect of reputation effects on bank returns.

\section{STUDY DESIGN}

Event Study is used to evaluate the occurrence of an event or the release of information, whether it will change the investor's decision, and thus affect the stock price or trading volume changes. The basic procedure of the event research method is firstly to use the sample of the estimation period to estimate the normal rate of return (or the expected rate of return) for the event period. Use the actual rate of return of the event period to deduct the expected rate of return to obtain an extraordinary rate of return for the period of the event. Finally, we test whether the sample cumulative abnormal return rate is significantly different from zero. This paper adopts the event study method to study the impact of reputation events on the market value of commercial banks. According to the "Guideline for the Management of Reputation Risk of Commercial Banks" of China Banking Regulatory Commission, a reputation event refers to a related behavior or event that triggers the reputation risk of a commercial bank. In this paper, the date of announcement of the reputation event is $t=0$, the window period of the event is $\left(t_{1}, t_{2}\right)$, and the estimated window period is $\left(t_{0}, t_{1}\right)$. In this article, a total of 5 days, 2 days before and after the date of the event, will be used as the event window period, and the 60 days before the event window period will serve as the estimated window period.

This paper uses a market model to estimate the expected rate of return for the window of events. The advantage of the market model is that it eliminates the portion of individual stock returns that is linked to the fluctuation of market returns and separates the impact of reputation events on the stock returns of commercial banks. This reduces the variance of the extraordinary return rate and helps to increase our calibrating effect on the event.

Expected rate of return is as follows:

$$
R_{i t}=\alpha_{i}+\beta_{i} M R_{i t}+\varepsilon_{i}
$$

$$
E R_{i t}=\hat{\alpha}_{i}+\hat{\beta}_{i} M R_{i t}
$$

where $R_{i t}$ is the actual rate of return of a sample bank on date $t, M R_{i t}$ is the rate of return of the market portfolio on date $t, \varepsilon_{i t}$ is the random error term, $\alpha_{\mathrm{i}}$ is the intercept term, and $\beta_{\mathrm{i}}$ is the correlation coefficient. For the return on market portfolio, this paper selects the Shanghai Composite Index to represent $M R_{i t}$. Using the actual rate of return of the estimated window period and the market portfolio data to calculate the $\hat{\alpha}_{i}$ and $\hat{\beta}_{i}$, then we can get the expected rate of return $E R_{i t}$ in the event window period.

The abnormal return rate is the abnormal change of the stock price caused by the occurrence of a reputation event. It is represented by the difference between the actual rate of return and the expected rate of return during the event. The abnormal return rate is as follows:

$$
A R_{i t}=R_{i t}-E R_{i t}
$$

where $A R_{i t}$ is an abnormal return rate, $R_{i t}$ is the actual rate of return, that is, the return rate of a bank's $t$ daily stocks, $E R_{i t}$ is the expected rate of return. As a result, the abnormal return rate is as follows:

$$
A R_{i t}=R_{i t}-\alpha_{i}-\beta_{i} M R_{i t}
$$

The cumulative abnormal return is the sum of the abnormal returns during the event window period. It can measure the losses caused by reputation events to commercial banks. The cumulative abnormal returns of the $\mathrm{N}$ commercial banks during the event window period $\left(t_{1}, t_{2}\right)$ is as follows:

$$
\operatorname{CAR}_{\left(t_{1}, t_{2}\right)}=\sum_{t=t_{1}}^{t_{2}} A R_{i t}
$$

If the reputation event has no effect on the bank's stock market return, the expectation of cumulative abnormal returns in the event window period should be 0 , so the following assumptions are made:

$\mathrm{H}_{0}$ : If $C A R_{\left(t_{1}, t_{2}\right)}=0$, then the reputation event has no effect on the commercial bank stock returns, that is, it does not affect the commercial bank's market value.

$\mathrm{H}_{1}$ : If $C A R_{\left(t_{1}, t_{2}\right)}<0$, the reputation event reduces the stock returns of commercial banks and reduces the market value of commercial banks.

For the calculated abnormal returns, this paper uses the ttest to test its significance.

\section{DATE AND EMPIRICAL RESULTS}

A. Date

Up to now, there are 25 listed commercial banks in China. Since Agricultural Bank and Everbright Bank were listed in 2010, and a number of city commercial banks were listed in recent years, there are fewer samples of reputation risk events.Therefore, this paper selected 68 listed reputation events of 14 listed banks from 2010 to 2018 as samples. The 14 listed commercial banks are Pudong Development Bank, Huaxia 
Bank, Minsheng Bank, China Merchants Bank, Nanjing Bank, Industrial Bank, Bank of Beijing, Agricultural Bank of China, Bank of Communications, Industrial and Commercial Bank of
China, Everbright Bank, China Construction Bank, China CITIC Bank, Ping An Bank.

TABLE I. NUMBER OF REPUTATION EVENTS

\begin{tabular}{|l|l|l|l|l|l|l|}
\hline \multirow{2}{*}{ Year } & \multicolumn{9}{|c|}{ Type of Reputation Events } & \multicolumn{2}{c|}{$\begin{array}{c}\text { Financial } \\
\text { performance }\end{array}$} \\
\cline { 2 - 7 } & Leader-ship & $\begin{array}{c}\text { Produ-cts and } \\
\text { Services }\end{array}$ & $\begin{array}{c}\text { Social } \\
\text { responsibility }\end{array}$ & Surroundings & $\begin{array}{c}\text { Corporate } \\
\text { influence }\end{array}$ & 0 \\
\hline 2010 & 0 & 2 & 1 & 0 & 0 & 0 \\
\hline 2011 & 2 & 1 & 0 & 1 & 0 & 0 \\
\hline 2012 & 3 & 4 & 1 & 1 & 0 & 1 \\
\hline 2013 & 0 & 2 & 1 & 0 & 1 & 0 \\
\hline 2014 & 2 & 3 & 0 & 0 & 1 & 0 \\
\hline 2015 & 6 & 4 & 0 & 1 & 0 & 1 \\
\hline 2016 & 1 & 8 & 0 & 3 & 0 & 0 \\
\hline 2017 & 4 & 6 & 2 & 1 & 1 & 0 \\
\hline 2018 & 0 & 1 & 1 & 1 & 0 & 0 \\
\hline
\end{tabular}

As shown in "Table I", from the longitudinal comparison, reputation events have increased in recent years. The number of reputation events that took place in the past two years accounted for $19 \%$, and the number of reputation events that occurred in 2010 accounted for $7 \%$. This shows that with the rapid development of new media and economy, the probability of outbreaks of reputation events and the speed of dissemination have greatly increased. The management of reputation risk should be a matter of importance to all major commercial banks.

In terms of horizontal comparison, this article uses RQ reputation quotients to classify them into five categories according to the constituent factors of reputation events: products and services, leadership, social responsibility, environment, corporate influence, and financial performance. Corporate influence includes respect, trust, and good impression of the company. In this article, it mainly refers to the ratings of rating agencies; products and services refer to the quality of products and services, including wealth management products and debt defaults; leadership refers mainly to the behavior of bank executives; the environment includes highquality employees; financial performance refers to risks resistance and profitability; and social responsibility mainly refers to the huge administrative penalty. Among them, the proportion of reputation events caused by products and services is the largest, with a proportion of up to $50 \%$, and the average return rate of stocks on the day of the event announcement is $0.11 \%$; The proportion of reputation events triggered by the behavior of executives was $26 \%$, and the stock yield on the day of the event fell $0.84 \%$ on average. This shows that executives' behavior has a greater impact on bank value. For other incidents of reputation events, no comparison is made here due to the small sample size.

\section{EMPIRICAL RESULTS AND ANALYSIS}

First, we test whether the cumulative abnormal returns of individual samples are significant. We calculate the standard deviation of the abnormal returns of each company in the event window period, calculate the $\mathrm{t}$ statistic and the $\mathrm{p}$ value, and create a new textual variable sig. Its values are ' $* * *$ ', ' $* *$ ', and '*', which are significant at the $1 \%, 5 \%$, and $10 \%$ levels, respectively.
TABLE II. Statistical Test of CUMUlative ABnormal Return RATE OF SIGNIFICANCE FOR INDIVIDUAL SAMPLES

\begin{tabular}{|l|l|l|l|l|l|}
\hline $\begin{array}{c}\text { Securities } \\
\text { code }\end{array}$ & Event date & CAR & t-Test & P value & Sig \\
\hline 601288 & $2015-04-23$ & -0.0515 & -8.7163 & 0.0001 & $* * *$ \\
\hline 601009 & $2015-08-17$ & -0.0653 & -3.4470 & 0.0005 & $* * *$ \\
\hline 601939 & $2015-05-19$ & -0.0383 & -2.7883 & 0.0052 & $* * *$ \\
\hline 000001 & $2010-10-22$ & -0.0674 & -4.5975 & 0.0056 & $* * *$ \\
\hline 600015 & $2015-05-04$ & -0.0697 & -2.7562 & 0.0058 & $* * *$ \\
\hline 601998 & $2016-01-29$ & -0.0299 & -2.6325 & 0.0084 & $* * *$ \\
\hline 600015 & $2011-10-19$ & -0.0750 & -3.5584 & 0.0003 & $* * *$ \\
\hline 600016 & $2016-08-19$ & -0.0137 & -2.3972 & 0.0165 & $* *$ \\
\hline 601009 & $2016-02-02$ & -0.0183 & -2.2800 & 0.0226 & $* *$ \\
\hline 601166 & $2016-12-26$ & -0.0111 & -1.6450 & 0.0999 & $*$ \\
\hline 600016 & $2015-01-30$ & -0.0324 & -1.7955 & 0.0725 & $*$ \\
\hline 601818 & $2013-06-07$ & 0.0299 & 1.6479 & 0.0993 & $*$ \\
\hline 600015 & $2017-09-04$ & -0.0220 & -1.7265 & 0.0842 & $*$ \\
\hline
\end{tabular}

As shown in "Table II", the occurrence of reputation events has different effects on individual banks. In the total sample, the cumulative abnormal returns in the event window period account for about $20 \%$. For this result, the explanation of this paper is that because of the different nature of reputation events and the persistence of impact, the impact on banks is different.

TABLE III. Statistical Test of Cumulative ABnORMal Returns FOR ALL SAMPLE

\begin{tabular}{|l|l|l|l|l|}
\hline $\begin{array}{c}\text { the } \\
\text { window } \\
\text { period }\end{array}$ & $\mathbf{N}$ & Mean-CAR & SD-CAR & P value \\
\hline$(0,0)$ & 68 & -0.0024 & 0.0270 & 0.0000 \\
\hline$(-1,-1)$ & 68 & -0.0042 & 0.0233 & 0.0000 \\
\hline$(-2 .-2)$ & 68 & -0.0073 & 0.0229 & 0.0007 \\
\hline
\end{tabular}

From "Table III", we can see that at the significance level of 0 in the event window periods of $(0,0)$ and $(-1,+1)$, we reject the original hypothesis that the total sample cumulative abnormal return rate is zero. This shows that reputation events have an impact on the market value of commercial banks, and negative reputation events will lead to a drop in the bank's share price.

Finally, this paper presents the temporal characteristics of cumulative abnormal returns more intuitively by using graphs. 


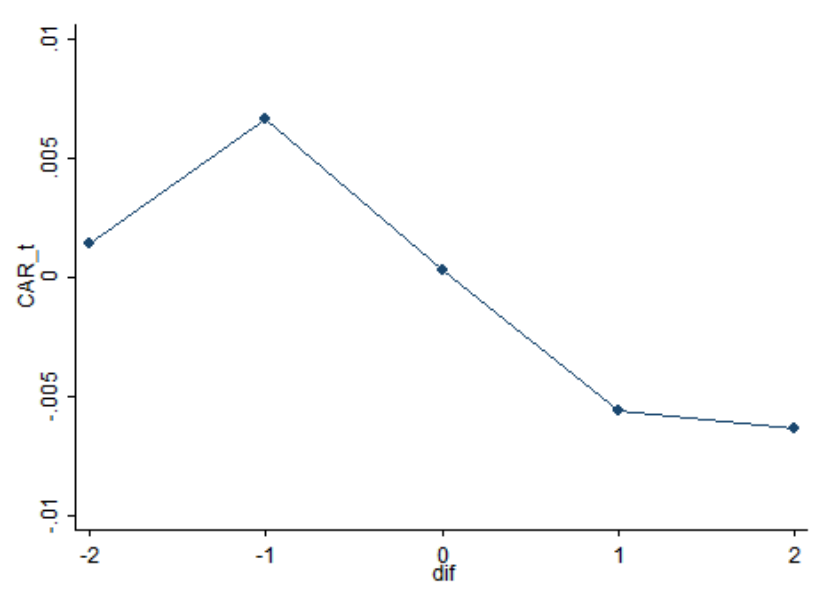

Fig. 1. The temporal characteristics of cumulative abnormal return rate in event window period.

As shown in "Fig. 1", prior to the announcement date of the reputation event, CAR did not show a downward trend; on the day of the event announcement, CAR showed a downward trend; on the day after the event was announced, the downward trend of CAR was still significant; On the second day after the announcement of the event, the decline in CAR slowed markedly. By the timing diagram of cumulative abnormal returns, this paper draws the following conclusions: The significant impact of reputation events on the market value of commercial banks is mainly concentrated on the day and the next day of the date of the announcement of reputation events. The impact of reputation events is short-lived, but it does not mean that reputation events have little impact on the commercial banks.

\section{CONCLUSION}

The occurrence of a reputation event will trigger the fluctuation of the commercial bank's stock price, which will have a negative impact on the market value of the commercial bank. With the rapid development of new media, bank reputation risks have taken on new features. New media have increased the complexity, diversity, passiveness and disruption of bank reputation risk. China's commercial banks should strengthen the management of reputation risk and prevent the occurrence of reputation events from both internal and external factors.

From the perspective of the commercial banks themselves, the main factors that cause reputation events are the following: products and services, leadership, and the environment. First, commercial banks should improve the quality of their own products and services. Second, they must pay attention to the regular assessment and supervision of top management personnel. Finally, it is important to improve their business abilities and risk prevention capabilities. The prevention of reputation events is mainly due to the establishment of a reputation risk management mechanism within the bank, including risk prevention mechanisms, early warning mechanisms, resolving mechanisms, and evaluation mechanisms.
For external factors, commercial banks should learn to use the power of new media. On the one hand, commercial banks should expand and disseminate positive reputation events, and on the other hand, it is necessary to handle negative reputation events in a timely manner. Commercial banks should not only improve their ability to analyze big data, but also start emergency plans in the first instance of a reputation event. In addition, the use of new media to strengthen brand promotion and establish a responsible social image are also important measure to guard against reputation risks.

Reputation risk management plays an important role in the continuous and healthy development of commercial banks. Frequent reputation risk events also indicate that the reputation risk management system of commercial banks in China is not yet mature. All commercial banks should pay attention to the management of reputation risks, and combine the bank's business strategies to formulate a reputation risk management system suitable for the development of the bank. In addition, emergency plans must be established to improve the reputation risk management mechanism so as to promote the sustainable development of commercial banks.

\section{REFERENCES}

[1] G Gorton, "Bank suspension of convertibility," Journal of Monetary Economics, 1985, pp. 177-193.

[2] DW Diamond, "Reputation Acquisition in Debt Markets," Journal of Political Economy, 1989, pp. 828-862.

[3] J Corbett and J Mitchell, "Banking Crises and Bank Rescues: The Effect of Reputation,” Journal of Money Credit \& Banking, 2000, pp.474-512.

[4] Qiang Zhang and Min Hu, "Research on Measure of Reputation Risk of Commercial Bank in China Based on Bayesian Network," Theory and Practice in Finance and Economics, 2014, pp. 2-8.

[5] Yi Bi, "A Preliminary Study on Commercial Bank Reputation Risk Early Warning System-An Empirical Analysis Based on HarrisFombrun Model," Shanghai Finance, 2013, pp. 77-79+118.

[6] Weidong Li, Lihong Qi, and Zhiqiong Luo, "Research on the Construction of China's Commercial Bank Reputation Index System," financial Research, 2010, pp.155-168.

[7] Min Hu and Junying Han. "Measures of China's commercial banks' reputation risk economic capital," Finance Forum, 2014, pp. 67-72.

[8] Tianlei Pi and Lihong Yang, "Commercial Bank Operational Risk, Reputation Effect and Market Response," International Finance Research, 2015, pp. 77-87. 